\title{
Nitrogen transactions along the digestive tract of lambs concurrently infected with Trichostrongylus colubriformis and Ostertagia circumcincta
}

\author{
BY M. D. BOWN*, D. P. POPPI + AND A. R. SYKES \\ Animals and Veterinary Sciences Group, Lincoln University, Canterbury, New Zealand
}

(Received 10 July 1990-Accepted 19 December 1990)

\begin{abstract}
Twelve lambs, paired on the basis of live weight, were cannulated in the abomasum, in the proximal jejunum approximately $4 \mathrm{~m}$ distal to the pylorus and in the terminal ileum. Six were infected with 3000 Trichostrongylus colubriformis and 3000 Ostertagia circumcincta larvae each day for 18 weeks and the remainder were pair-fed to individual infected lambs. All animals were offered ryegrass (Lolium perenne)-white clover (Trifolium repens) pasture, cut daily. Dry matter (DM) intake, live weight, faecal egg concentration, plasma pepsinogen and plasma protein concentrations were measured weekly. During weeks 7 and 17 after commencement of infection, the flow of digesta along the gastrointestinal tract was measured together with enteric plasma loss and true digestion and absorption of ${ }^{125}$ I-labelled albumin in the small intestine. DM intake was depressed by parasitism, being 1331, (SE 70), 423 (SE 32) and 529 (SE 52) $\mathrm{g} / \mathrm{d}$ during weeks 3,7 and 17 respectively. The flow of nitrogen at the proximal jejunum and in faeces was increased by parasitism during week 7 and at the abomasum and ileum during week 17 . Plasma protein-N loss (g/d) into the gastrointestinal tract was 0.68 (SE 0.091) and 1.97 (SE 0.139) during week 7 , and 0.85 (SE 0.158) and 1.96 (SE 0.396 ) during week 17, in control and infected sheep respectively. True digestion and absorption of albumin in the proximal small intestine, the site of infection, was very low (mean 0.08) and was not affected by parasitism. Between the abomasum and terminal ileum absorption of albumin was high (mean 0.87 ) and again was not affected by parasitism. It was calculated that of the total increase in endogenous protein passing from the ileum tract as a result of infection, plasma protein comprised only a small percentage (10-36\%). The major proportion of digestion and absorption of protein occurred in the distal small intestine beyond the site of infection and was not affected by infection.
\end{abstract}

Trichostrongylus colubriformis: Ostertagia circumcincta : Protein absorption: Sheep

The sites of predilection of Ostertagia circumcincta and Trichostrongylus colubriformis in sheep are the abomasum and anterior small intestine respectively. The implications of pathological damage for protein digestion and subsequent absorption have not been established, partly because of uncertainty about the role of the abomasum and proximal small intestine in protein digestion and absorption, even in uninfected animals.

Studies of the peptidase activity of the gastrointestinal tract have shown values at the site of infection in the small intestine of only $17 \%$ of those in distal parts of the intestine (Richardson \& Jouan, 1986), and Jones (1982) showed no effect of infection with $T$. vitrinus on these activities. Infection with $T$. colubriformis is, however, associated with increased digesta nitrogen flow past the ileum (Poppi et al. 1986) which was considered not to be the

Present addresses: * Whatawhata Research Centre, Ministry of Agriculture \& Fisheries, Private Bag, Hamilton, New Zealand. $†$ Department of Agriculture, University of Queensland, St Lucia, Queensland 4067, Australia.

$\ddagger$ For reprints. 
result of malabsorption but of increased endogenous protein losses into the gastrointestinal tract. Plasma protein, epithelial cell desquamation and mucus secretion have each been implicated, although Symons \& Jones (1970) and Poppi et al. (1986) have suggested that they are largely digested and reabsorbed before the ileum. However, the extent of true digestion and absorption of endogenous protein is a matter for speculation.

The present study examined the digestion and absorption of protein across the site of infection in the proximal small intestine in lambs infected with $O$. circumcincta and $T$. colubriformis. Direct measurement of plasma protein absorption and other $\mathrm{N}$ transactions between sites in the gastrointestinal tract was made.

A preliminary report of some aspects of the present study has appeared (Bown et al. 1984).

\section{MATERIALS AND METHODS}

\section{General}

Twelve Dorset Down $\times$ Coopworth wether lambs were maintained at pasture from birth and drenched weekly from weaning at 9 weeks of age with Panacur (Coopers Animal Health (NZ) Ltd) at a rate of $5 \mathrm{mg}$ Fenbendazole $/ \mathrm{kg}$ live weight to limit parasitism. Before introduction into metabolism cages, all animals were dosed once with Ivomec (Merck, Sharp \& Dohme (NZ) Ltd) at a rate of $13 \mathrm{mg}$ Ivermectin $/ \mathrm{kg}$ live weight as an additional precaution.

At 3 months of age, T-shaped cannulas were inserted into the abomasum (approximately $10 \mathrm{~cm}$ anterior to the pylorus), into the proximal jejunum (approximately one-fifth of the length of the small intestine; 1/5 SI) and into the terminal ileum (approximately $80 \mathrm{~cm}$ anterior to the ileo-caecal junction). The site for placement of the cannula in the proximal jejunum (1/5 SI) was immediately distal to the expected site of the majority of the parasite burden (Barker, 1974; Coop et al. 1979) and, for ease of access, was inserted where the small intestine commenced attachment with the greater omentum. Normal intestinal cannulation techniques were used (Hecker, 1974). Post-mortem examination showed that the cannulas were $4 \cdot 28$ (SE 0.494$) \mathrm{cm}$ beyond the pylorus and, though variable in distance between animals, were a relatively constant proportion of the total length of the small intestine $(0 \cdot 19$ (SE 0.014)). Animals were allowed 4 weeks to recover from surgery before being paired on the basis of fasted live weight (mean 26.7 (SE 0.31 ) $\mathrm{kg}$ ) and put into metabolism cages where they were maintained under constant illumination. One animal of each pair was dosed orally with $3000 \mathrm{~T}$. colubriformis and $3000 \mathrm{O}$. circumcincta larvae daily for 18 weeks. Two batches of larvae of $O$. circumcincta were used, the first during weeks $1-12$, and the second for the remainder of the trial.

\section{Feeding}

All animals were offered, twice daily at 09.30 and 16.00 hours, fresh rygrass (Lolium perenne)-white clover (Trifolium repens) pasture which was cut daily. Infected animals were offered feed ad lib. (1.3 times the consumption of fresh freed on the previous day) while pair-fed controls received the amount of feed dry matter (DM) consumed by their infected pairs on the previous day. All animals were allowed free access to fresh tap water.

\section{Routine measurements}

Individual feed offered and refusals were subsampled daily; samples from each animal were combined on an equal weight basis within weeks and samples retained for $\mathrm{N}$ analysis. DM content was determined daily by drying to constant weight in a forced air draught oven at $70^{\circ}$. 
Table 1. Sequence of experimental procedures used during weeks 6-7 and 17-18 post-infection

\begin{tabular}{|c|c|}
\hline $\begin{array}{l}\text { Day of } \\
\text { measurement } \\
\text { period }\end{array}$ & Procedure \\
\hline 1 & $\begin{array}{l}\text { Injection of }{ }^{125} \text { I-labelled albumin and } \\
\text { Cr-EDTA into abomasum; collection of } \\
\text { digesta after appearance at proximal } \\
\text { jejunum and ileum }\end{array}$ \\
\hline 2 & $\begin{array}{l}\text { Start continuous infusion of }\left[{ }^{51} \mathrm{Cr}\right] \text { EDTA } \\
\text { and }\left[{ }^{103} \mathrm{Ru}\right] \mathrm{P} \text { for measurement of digesta } \\
\text { flow }\end{array}$ \\
\hline 7 & $\begin{array}{l}\text { Collection of digesta from abomasum } \\
\text { and ileum }\end{array}$ \\
\hline 8 & Collection from proximal jejunum \\
\hline 9 & Collection from abomasum and ileum \\
\hline 10 & $\begin{array}{l}\text { Collection from proximal jejunum: } \\
\text { infusion stopped after last sample }\end{array}$ \\
\hline $\begin{array}{l}11 \\
12 \\
13\end{array}$ & Clearance of $\left[{ }^{51} \mathrm{Cr}\right] \mathrm{EDTA}$ from GIT \\
\hline 14 & $\begin{array}{l}\text { Intrajugular injection of }{ }^{51} \mathrm{CrCl}_{3} \text { after } \\
\text { checking no background }\left[{ }^{51} \mathrm{Cr}\right] \mathrm{EDTA} \text { in } \\
\text { faeces }\end{array}$ \\
\hline 15 & Jugular blood sample and faecal sample \\
\hline 16 & daily for ${ }^{51} \mathrm{Cr}$ analysis to assess \\
\hline 17 & enteric plasma loss \\
\hline 18 & \\
\hline 19 & \\
\hline 20 & \\
\hline
\end{tabular}

GIT, gastrointestinal tract.

Faecal and urinary output were measured daily. Urine was acidified to $\mathrm{pH} 3-4$ with acetic acid. Subsamples of faeces and urine were bulked on a percentage basis ( $10 \%$ of daily production) within weeks for each animal and stored at $-20^{\circ}$ before laboratory analysis.

Faeces were taken each week from the rectum of each sheep and processed immediately to determine faecal egg concentration by the modified McMaster method (Ministry of Agriculture, Fisheries and Food, 1979). Blood samples were taken weekly by jugular venepuncture (into sodium heparin), the plasma being stored at $-18^{\circ}$ before analysis. Animals were weighed weekly before the morning feed.

\section{Digesta flow measurements}

Measurements of $\mathrm{N}$ transactions along the gastrointestinal tract were made during weeks 6-7 and weeks 17-18 post-infection. Routine live weight measurement and faeces, urine and blood collection were temporarily suspended. The experimental procedures are summarized in Table 1 . Feed was dispensed every $2 \mathrm{~h}$ from automatic feeders at a rate restricted to the mean consumption during the previous week. This allowed maintenance of 'steady state' conditions during the measurement of digesta flow.

Digesta flow past the three cannulas was measured with $\left[{ }^{51} \mathrm{Cr}\right]$ EDTA (Downes \& McDonald, 1964) and ${ }^{103} \mathrm{Ru}$-labelled Tris-(1, 10,-phenanthroline)-ruthenium II chloride $\left(\left[{ }^{103} \mathrm{Ru}\right] \mathrm{P}\right.$; Tan et al. 1971) and calculated according to Faichney (1975).

The markers were infused into the rumen via a temporary polyvinyl chloride catheter at the rate of approximately $40 \mathrm{ml} / \mathrm{d}$ (containing approximately $10 \mu \mathrm{Ci}\left[{ }^{103} \mathrm{Ru}\right] \mathrm{P}$ and 
$50 \mu \mathrm{Ci}\left[{ }^{51} \mathrm{Cr}\right] \mathrm{EDTA}$ ) for $8 \mathrm{~d}$. Over the last $4 \mathrm{~d}$, samples of digesta (approximately $150 \mathrm{~g}$ ) were taken at $6 \mathrm{~h}$ intervals from both abomasal and ileal cannulas on days 5 and 7 , and from the $1 / 5$ SI cannula on days 6 and 8 . Half the sample was strained on collection. Filtrate and whole digesta samples were each bulked on an equal weight basis before laboratory analyses.

\section{True digestibility and absorption of albumin}

True digestion and absorption of albumin across the proximal small intestine and between the abomasum and ileum was determined from the change in ${ }^{125}$ I-labelled albumin: $\left[{ }^{51} \mathrm{Cr}\right]$ EDTA ratio in digesta collected from the two intestinal cannulas after injection into the abomasum. Approximately $15 \mu \mathrm{Ci}{ }^{125} \mathrm{I}$-labelled human albumin, from which free iodide was removed by adsorption using IRA-400 ion exchange resin (Mallinckrodt Inc., USA), and $40-60 \mu \mathrm{Ci}\left[{ }^{51} \mathrm{Cr}\right] \mathrm{EDTA}$ with appropriate carrier were injected simultaneously into the abomasum. At least three samples of digesta (approximately $50 \mathrm{~g}$ ) were collected after the first appearance of marker at each cannula. Approximately $15 \mathrm{~min}$ were allowed to elapse between samples at the $1 / 5$ SI cannula to allow a relatively uninterrupted flow of digesta to the distal regions of the small intestine. This was not necessary when sampling at the terminal ileum. Transit time was the difference between the time of injection of marker into the abomasum and time for first appearance of marker at the respective cannulas.

\section{Enteric plasma loss}

Plasma loss into the gastrointestinal tract was measured by reference to the excretion of ${ }^{51} \mathrm{CrCl}_{3}$ in the faeces after jugular injection of approximately $300 \mu \mathrm{Ci}^{51} \mathrm{CrCl}_{3}$ using the methods of Holmes \& MacLean (1971). Injection was extended over a period of 1-2 min to allow maximum distribution of isotope in the plasma pool. Blood sampling commenced $24 \mathrm{~h}$ after injection. The corresponding faecal collection period was then started. All animals were equipped with faecal collection bags to prevent contamination of faeces with radioactive urine. Blood samples and faeces were collected daily for $6 \mathrm{~d}$. Enteric plasma volume and protein loss into the gastrointestinal tract was calculated according to Herd (1971).

\section{Laboratory analysis}

Feeds, refusals and faeces were freeze-dried and ground through a $1 \mathrm{~mm}$ screen before chemical analysis. DM was checked by oven-drying subsamples at $70^{\circ}$. DM content of digesta samples was also determined by drying subsamples to constant weight at $70^{\circ}$. Other analyses of digesta samples were performed on fresh samples.

Total $\mathrm{N}$ content of feeds, refusals, faeces, urine and digesta was determined after Kjeldahl digestion using an adaptation of the methods of Bradstreet (1965). Non-ammonia $\mathrm{N}$ (NAN) in digesta samples was calculated as the difference between total $\mathrm{N}$ and $\mathrm{NH}_{3}-\mathrm{N}$ after correction for $\mathrm{DM}$ content, assuming that all $\mathrm{NH}_{3}-\mathrm{N}$ was associated with the liquid phase. $\mathrm{NH}_{3}-\mathrm{N}$ in fresh digesta samples was determined by steam distillation of the sample (using saturated sodium tetraborate as a base) into boric acid followed by titration against hydrochloric acid.

Organic matter (OM) content of dry feeds, refusals, faeces and digesta samples was determined from weight loss after incineration at $575^{\circ}$ for $10 \mathrm{~h}$.

Total protein concentration in plasma was determined using the method of Wolfson et al. (1948), and plasma albumin concentration using ovine serum albumin fraction $\mathrm{V}$ (Sigma, USA) as a standard. Globulin concentration was taken as the difference between total protein and albumin concentration (Steel et al. 1980). 
Pepsinogen concentration of weekly plasma samples was determined according to the method of Jones (1979).

\section{Determination of radioactivity in samples}

Analysis of radioactivity of ${ }^{51} \mathrm{Cr}$ and ${ }^{103} \mathrm{Ru}$ in samples was performed simultaneously using an Autogamma scintillation spectrometer (Model 5110, Packard, USA). ${ }^{51} \mathrm{CrCl}_{3}$ was analysed using a Tri-Carb auto-gamma spectrometer (Model 3001, Packard, USA) which allowed determination of radioactivity in a relatively large volume of faeces (up to $500 \mathrm{~g}$ ). ${ }^{51} \mathrm{CrCl}_{3}$ in corresponding plasma samples was analysed using the same machine but with correction for difference in geometry of the samples.

\section{Statisical analysis}

The experiment was analysed statistically as a randomized block design with two animals per block.

Each response variate was examined using the GENSTAT statistical software package (release 4.04B; Rothamstead Experimental Station, England). Mean effect over time was calculated and subjected to analysis of variance with consideration of variation between treatments and between animals within treatments. These data were also examined by analysis of variance at each time separately using the same criteria.

\section{RESULTS}

At 3 weeks after the start of the experiment one infected animal died due to enterotoxaemia and this sheep and its partner were excluded from the experiment.

\section{$D M$ intake and liveweight changes}

Due to seasonal changes in pasture composition during the experimental period (JanuaryApril) feed quality, in particular $\mathrm{N}$ content, varied during the experiment $(24 \cdot 3-44 \cdot 3 \mathrm{~g} \mathrm{~N} / \mathrm{kg}$ DM). In addition, DM content of the herbage varied from day to day $(115-202 \mathrm{~g} / \mathrm{kg}) \mathrm{due}$ to local weather conditions. Consistent pair-feeding was not established until the third week after initial infection but was consistent thereafter, though due to difficulty in adjusting for the daily variation in herbage DM, pair-fed animals consumed approximately $10 \%$ less DM than the infected animals.

Mean DM intake was reduced by parasitism after the third week of infection (Fig. 1), and was 1331 (SE 70), 423 (SE 32) and 529 (SE 52) g DM/d respectively during weeks 3, 7 and 17 for the parasitized group. Dry matter, $\mathrm{OM}$ and $\mathrm{N}$ apparent digestibilities were not affected by parasitism (Table 2 ).

Since pair-feeding was not completely established until 3 weeks postinfection, the liveweight values from week 3 onwards were subjected to covariance analysis on live weight at week 3. The adjusted means are presented in Fig. 2. The mean live weight over the experiment was not different between infected and control animals $(P=0 \cdot 12)$. However, during weeks 14,17 and 18 the live weight of infected animals was significantly less than that of the control $(P<0.05)$.

\section{Faecal egg output}

Parasite eggs were first detected in the faeces $21 \mathrm{~d}$ after initial infection and reached a peak value of 4560 eggs/g faeces (epg) (SE 1370) during week 12. Thereafter, faecal egg concentration declined rapidly to 1260 epg faeces (SE 354) during week 18 . However, peak total faecal egg output was $2.15 \times 10^{6}\left(\mathrm{SE} 1.35 \times 10^{6}\right)$ eggs/d during week 10 . 


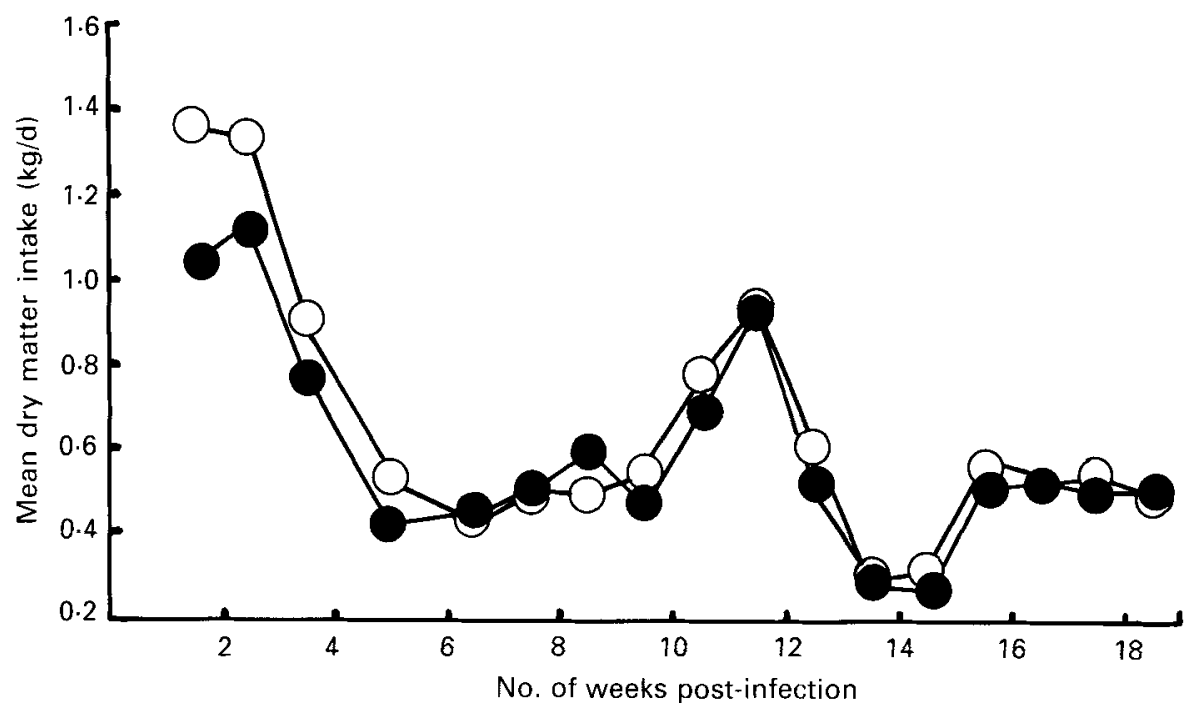

Fig. 1. Mean dry-matter intake (kg/d) of lambs infected daily with 3000 Trichostrongylus colubriformis and 3000 Ostertagia circumcincia larvae $(O)$ and of their pair-fed controls (O) over 18 weeks.

Table 2. Mean digestibility coefficients for lambs 3, 6, 10 and 16 weeks after commencement of infection with Ostertagia circumcincta and Trichostrongylus colubriformis $(P)$ and for their controls $(C)$

\begin{tabular}{|c|c|c|c|c|c|c|c|c|}
\hline \multirow[t]{2}{*}{ Week after infection... } & \multicolumn{2}{|c|}{3} & \multicolumn{2}{|c|}{6} & \multicolumn{2}{|c|}{10} & \multicolumn{2}{|c|}{16} \\
\hline & $P$ & $\mathrm{C}$ & $\mathbf{P}$ & $\mathrm{C}$ & $P$ & $\mathrm{C}$ & $\mathrm{P}$ & $\mathrm{C}$ \\
\hline DM intake $(\mathrm{g} / \mathrm{d})$ & 1331 & 1134 & 525 & 427 & 544 & 467 & 565 & 512 \\
\hline SED & \multicolumn{2}{|c|}{196.9} & \multicolumn{2}{|c|}{$167 \cdot 7$} & \multicolumn{2}{|c|}{$147 \cdot 0$} & \multicolumn{2}{|c|}{$210 \cdot 6$} \\
\hline DMD $(\%)$ & $80 \cdot 6$ & $75 \cdot 7$ & $81 \cdot 5$ & $79 \cdot 0$ & $73 \cdot 1$ & $71 \cdot 9$ & $76 \cdot 3$ & $73 \cdot 2$ \\
\hline SED & \multicolumn{2}{|c|}{3.23} & \multicolumn{2}{|c|}{$2 \cdot 33$} & \multicolumn{2}{|c|}{5.50} & \multicolumn{2}{|c|}{3.52} \\
\hline OM intake $(\mathrm{g} / \mathrm{d})$ & 1215 & 1038 & 478 & 388 & 488 & 419 & 514 & 464 \\
\hline SED & \multicolumn{2}{|c|}{$180 \cdot 1$} & \multicolumn{2}{|c|}{$152 \cdot 4$} & \multicolumn{2}{|c|}{131.6} & \multicolumn{2}{|c|}{$191 \cdot 5$} \\
\hline OMD $(\%)$ & $82 \cdot 2$ & $77 \cdot 7$ & $84 \cdot 6$ & $82 \cdot 5$ & $75 \cdot 9$ & $75 \cdot 5$ & $81 \cdot 0$ & $78 \cdot 5$ \\
\hline SED & \multicolumn{2}{|c|}{$18 \cdot 35$} & \multicolumn{2}{|c|}{1.95} & \multicolumn{2}{|c|}{$4 \cdot 18$} & \multicolumn{2}{|c|}{$2 \cdot 79$} \\
\hline $\mathrm{N}$ intake $(\mathrm{g} / \mathrm{d})$ & $41 \cdot 1$ & $33 \cdot 5$ & $21 \cdot 4$ & $17 \cdot 7$ & $21 \cdot 5$ & $18 \cdot 4$ & $22 \cdot 7$ & $20 \cdot 8$ \\
\hline SED & \multicolumn{2}{|c|}{5.92} & \multicolumn{2}{|c|}{6.95} & \multicolumn{2}{|c|}{5.60} & \multicolumn{2}{|c|}{8.79} \\
\hline $\mathrm{N}$ digestibility $(\%)$ & $79 \cdot 8$ & $73 \cdot 3$ & $81 \cdot 1$ & $79 \cdot 9$ & $74 \cdot 2$ & $73 \cdot 7$ & $76 \cdot 8$ & $74 \cdot 2$ \\
\hline SED & \multicolumn{2}{|c|}{3.58} & \multicolumn{2}{|c|}{2.56} & \multicolumn{2}{|c|}{4.53} & \multicolumn{2}{|c|}{$3 \cdot 35$} \\
\hline
\end{tabular}

SED, standard error of difference (df 4); DM, dry matter; DMD, dry matter digestibility; OM, organic matter ; OMD, organic matter digestibility.

\section{Blood biochemical changes}

The changes in concentration of total protein, albumin and globulin in plasma in infected and pair-fed controls during the experiment are shown in Fig. 3. Infection reduced mean plasma total protein $(P<0 \cdot 1)$ and mean plasma albumin $(P<0.01)$ concentrations over the experiment, although plasma globulin concentration was similar in infected and control animals throughout the experiment. Fig. 4 shows plasma pepsinogen concentrations of infected and control animals during the experiment. Mean pepsinogen concentration over 


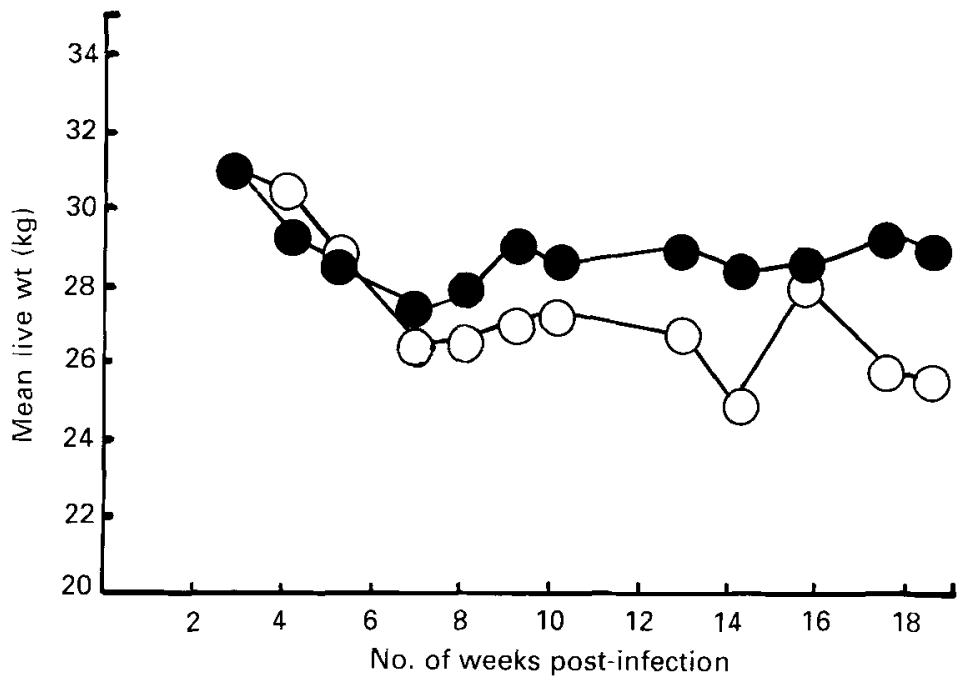

Fig. 2. Mean liveweight $(\mathrm{kg})$ of lambs infected daily with 3000 Trichostrongylus colubriformis and 3000 Ostertagia circumcincta larvae $(O)$ and of their pair-fed controls $(\mathbf{O})$ adjusted for variation in live weight at week 3 (after the establishment of pair-feeding).

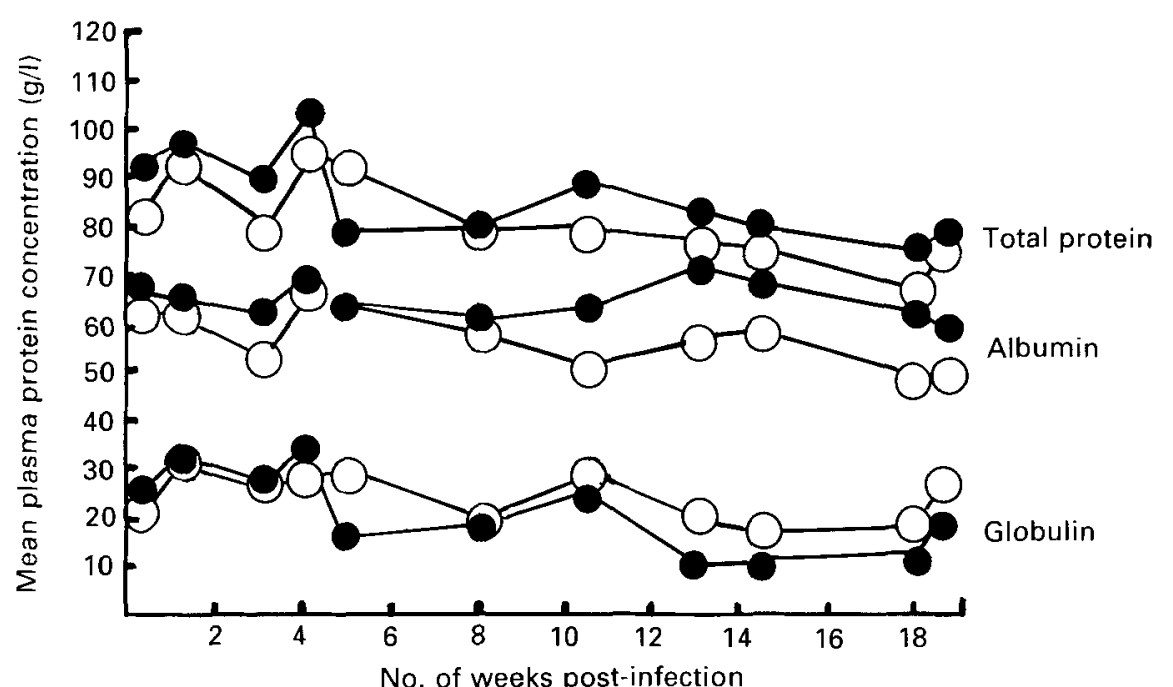

Fig. 3. Mean concentration of plasma proteins ( $\mathrm{g} / 1$ plasma) in lambs infected daily with 3000 Trichostrongy/us colubriformis and 3000 Ostertagia circumcincta larvae $(O)$ and of their pair-fed controls $(O)$ over 18 weeks.

the experiment was similar in infected and control animals, although during weeks $5,9,11$ and 14 pepsinogen concentration was higher in infected than control animals $(P<0.05$ in week $5, P<0 \cdot 1$ in weeks 9,11 and 14 ).

\section{$N$ transactions along the gastrointestinal tract}

Plasma protein $\mathrm{N}$ loss into the gastrointestinal tract was increased two- to threefold by parasitism during weeks 7 and $17\left(P<0.05\right.$; Table 3). The absorption of ${ }^{125}$ I-labelled albumin across the whole small intestine was high (0.87) and similar in infected and control 


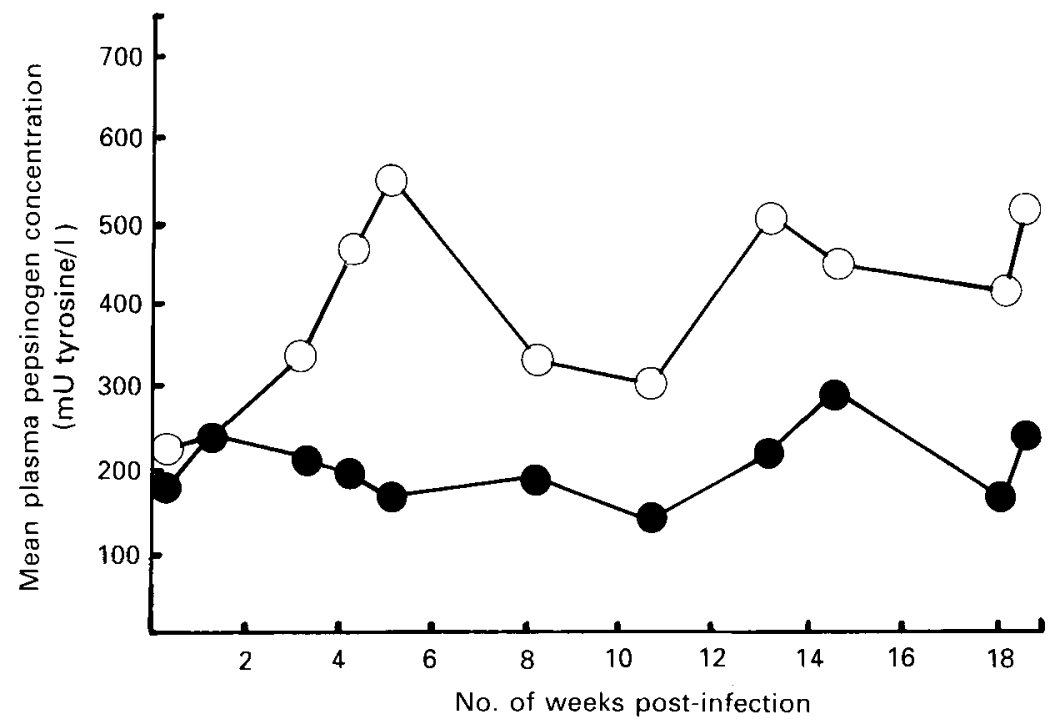

Fig. 4. Mean concentration of plasma pepsinogen ( $\mathrm{mU}$ tyrosine/l) in lambs infected daily with 3000 Trichostrongylus colubriformis and 3000 Ostertagia circumcincta larvae $(O)$ and of their pair-fed controls over 18 weeks.

Table 3. Effect of a concurrent infection of Ostertagia circumcincta and Trichostrongylus colubriformis on mean plasma protein-nitrogen loss, absorption of albumin, digesta transit across the small intestine and digesta $\mathrm{pH}$ in lambs 7 and 17 weeks after commencement of dosing with the parasites

(Mean values for five lambs)

\begin{tabular}{|c|c|c|c|c|}
\hline \multirow{2}{*}{$\begin{array}{l}\text { Period after infection (weeks)... } \\
\text { Treatment ... }\end{array}$} & \multicolumn{2}{|c|}{7} & \multicolumn{2}{|c|}{17} \\
\hline & Control & Infected & Control & Infected \\
\hline $\begin{array}{l}\text { Plasma protein-N, } \\
\text { loss }(\mathrm{g} \mathrm{N} / \mathrm{d})\end{array}$ & $0.68^{* *}$ & $1.97^{* *}$ & $0 \cdot 85^{*}$ & $1.96^{*}$ \\
\hline \multicolumn{5}{|l|}{$\begin{array}{l}\text { True absorption of } \\
{ }^{125} \text { I-labelled albumin: }\end{array}$} \\
\hline $\begin{array}{l}\text { Proximal jejunum } \\
\text { SED }\end{array}$ & $0.06^{*}$ & $0 \cdot 01^{*}$ & 0.072 & $0 \cdot 12$ \\
\hline $\begin{array}{l}\text { Small intestine } \\
\text { SED }\end{array}$ & \multicolumn{2}{|c|}{$0 \cdot 018$} & 0.88 & 0.86 \\
\hline $\begin{array}{l}\text { Transit time (min): } \\
\text { Proximal jejunum } \\
\text { SED }\end{array}$ & $10 \cdot 7$ & $11 \cdot 2$ & $7 \cdot 8$ & $14 \cdot 0$ \\
\hline $\begin{array}{l}\text { Small intestine } \\
\text { SED }\end{array}$ & $150^{*}$ & $204^{*}$ & \multicolumn{2}{|c|}{$33 \cdot 5$} \\
\hline $\mathrm{pH}$ & & & & \\
\hline $\begin{array}{l}\text { Abomasum } \\
\text { SED }\end{array}$ & \multicolumn{2}{|c|}{$0.2 \mathrm{I}$} & \multicolumn{2}{|c|}{0.22} \\
\hline $\begin{array}{l}\text { Proximal jejunum } \\
\text { SED }\end{array}$ & $4 \cdot 9$ & $5 \cdot 1$ & $4 \cdot 7$ & $4 \cdot 8$ \\
\hline
\end{tabular}

Mean values for infected animals were significantly different to those for controls; ${ }^{*} P<0.05,{ }^{* *} P<0.01$ SED, standard error of difference (df 4$)$. 
animals at both periods. Absorption across the duodenum was low $(0.08)$ in infected and control animals and, though significantly less in infected animals during week 7 , was similar in both periods (Table 3 ).

Although there was little absolute effect of infection on $\mathrm{pH}$ of abomasal and duodenal digesta (Table 3), values for abomasal $\mathrm{pH}$ in infected animals were significantly elevated $(P<0.05)$ during week 7.

Digesta transit across the proximal small intestine was rapid (mean $10.9 \mathrm{~min}$ ) and was not affected by parasitism (Table 3). However, parasitism delayed transit of digesta across the whole small intestine by approximately 50 min during weeks 7 and 17 though the effect was significant $(P<0.05)$ only during week 7 .

The regression equations relating total $\mathrm{N}$ and NAN flow past the abomasum, proximal jejunum, terminal ileum, and total $\mathrm{N}$ in faeces with $\mathrm{N}$ intake were highly significant $(P<0.05)$ with $r^{2}$ values in the range 0.73-0.99. Treatment and period effects were estimated after analysis of covariance on $\mathrm{N}$ intake and adjusted values are given in Tables 4 and 5 . Flow of both $\mathrm{N}$ and NAN past the digesta sampling sites was greater in infected than in control animals at the abomasum, proximal jejunum and terminal ileum during week $17(P<0.05)$. Statistically significant differences were not demonstrated during week 7 by this method. The regression equations relating flow of $N$ and NAN at the abomasum and $\mathrm{N}$ intake had different intercepts $(P<0.1)$ reflecting additional flow of $1.6 \mathrm{~g} \mathrm{~N} / \mathrm{d}$ and $1.2 \mathrm{~g} \mathrm{NAN} / \mathrm{d}$ at this site in infected animals.

\section{DISCUSSION}

The animal numbers used in the present experiment are low given the difficulty of obtaining a similar level of pathogenicity in the treated animals. The results were analysed using standard statistical assumptions such as normality of error distribution, although variability in host susceptibility to parasite infection is quite possible. With the exception of the flow results of one animal in week 7 , there was no evidence that any individual animal markedly influenced the treatment effects.

The object of the present work was to determine the extent to which plasma protein lost into the gastrointestinal tract is re-absorbed and the importance of a major site of infection with nematode parasites in this process. The coefficient of absorption of albumin in the whole of the small intestine was high $(0-87)$ and is similar to a coefficient for total endogenous protein absorption of 0.86 calculated from the values of Lindsay et al. (1980). Thus, although plasma protein $\mathrm{N}$ loss into the gastrointestinal tract was increased two-to threefold by infection (Table 3), in agreement with the findings of Steel et al. (1982) for a similar mixed nematode infection, most of this would have been re-absorbed before the terminal ileum, assuming that all plasma protein loss occurs at the site of infection.

This appears to be the first investigation to demonstrate conclusively that the first onefifth of the small intestine, the site of habitation of the majority of the $T$. colubriformis worm burden (Barker, 1974; Coop et al. 1979), is unimportant for digestion of simple proteins such as albumin and that such protein digestion normally occurs beyond the site of infection. It confirms the low net disappearance of NAN in the proximal region and high disappearance in the mid region of the small intestine observed by Ben-Ghedalia et al. (1974), and explains the findings of the previous studies of Symons \& Jones (1970), Poppi et al. (1986) and Rowe et al. (1988) of the lack of effect of gastrointestinal parasitism on protein digestion and absorption. Three reasons can be advanced for the unimportance of the proximal small intestine for protein digestion. First, the $\mathrm{pH}$ of digesta in this region was low (Table 3), which Ben-Ghedalia et al. (1974) and Armstrong \& Hutton (1975) showed to be inappropriate for protease activity. Second, peptidase activity in the mucosa 
Table 4. Total nitrogen flow (adjusted for variation in $N$ intake; mean $20.6 \mathrm{~g} \mathrm{~N} / \mathrm{d}$ ) past the abomasum, proximal jejunum and terminal ileum, and total faecal $N$ output of lambs concurrently infected with Ostertagia circumcincta and Trichostrongylus colubriformis and of their pair-fed controls

(Mcan values for five lambs)

\begin{tabular}{|c|c|c|c|c|c|}
\hline \multirow{2}{*}{$\begin{array}{l}\text { Period after infection (weeks)... } \\
\text { Treatment... }\end{array}$} & \multicolumn{2}{|c|}{7} & \multicolumn{2}{|c|}{17} & \multirow[b]{2}{*}{ SED } \\
\hline & Control & Infected & Control & Infected & \\
\hline Abomasal $\mathrm{N}$ flow $(\mathrm{g} / \mathrm{d})$ & $16 \cdot 2$ & $15 \cdot 3$ & $17 \cdot 2$ & $22 \cdot 7^{*}$ & 2.03 \\
\hline Jejunal $N$ flow $(g / d)$ & $15 \cdot 2$ & $18 \cdot 2$ & $16 \cdot 7$ & $23 \cdot 3^{*}$ & 2.61 \\
\hline Ileal $\mathrm{N}$ flow $(\mathrm{g} / \mathrm{d})$ & 5.89 & $6 \cdot 22$ & 5.69 & $7 \cdot 54^{*}$ & 0.742 \\
\hline Faecal $N$ output $(\mathrm{g} / \mathrm{d})$ & 2.78 & $3 \cdot 35$ & 3.63 & 3.65 & 0.321 \\
\hline
\end{tabular}

Mean values for infected animals were significantly different to those for controls: ${ }^{*} P<0.05$.

SED, standard error of difference between parasite treatment effects (df 7 , pooling between pairs and pairs $\times$ treatment sums of squares, and allowing for the covariate).

Table 5. Non-ammonia-nitrogen (NAN) flow (adjusted for variation in $N$ intake; mean $20.6 \mathrm{~g} \mathrm{~N} / \mathrm{d}$ ) past the abomasum, proximal jejunum and terminal ileum of lambs concurrently infected with Ostertagia circumcincta and Trichostrongylus colubriformis and for their pairfed controls

(Mean values for five lambs)

\begin{tabular}{|c|c|c|c|c|c|}
\hline \multirow{2}{*}{$\begin{array}{l}\text { Period after infection (weeks)... } \\
\text { Treatment... }\end{array}$} & \multicolumn{2}{|c|}{7} & \multicolumn{2}{|c|}{17} & \multirow[b]{2}{*}{ SED } \\
\hline & Control & Infected & Control & Infected & \\
\hline Abomasal NAN flow $(\mathrm{g} / \mathrm{d})$ & $14 \cdot 9$ & {$[4 \cdot 1$} & $16 \cdot 0$ & $20 \cdot 9 *$ & $1 \cdot 81$ \\
\hline Jejunal NAN flow $(\mathrm{g} / \mathrm{d})$ & $13 \cdot 7$ & $16 \cdot 3$ & $15 \cdot 2$ & $20 \cdot 8^{*}$ & $2 \cdot 36$ \\
\hline Ileal NAN flow $(\mathrm{g} / \mathrm{d})$ & $5 \cdot 03$ & $5 \cdot 23$ & 4.98 & $6 \cdot 55$ & 0.656 \\
\hline
\end{tabular}

Mean values for infected animals were significantly different to those for controls: ${ }^{*} P<0.05$.

SED, standard error of difference between parasite treatment effects (df 7 , pooling between pairs and pairs $\times$ treatment sums of squares, and allowing for the covariate).

of this region is only one-sixth of that in more distal regions of the tract (Richardson \& Jouan, 1986). Third, the transit time of digesta through this region of the intestine was extremely rapid compared to that in the whole small intestine (Table 3 ).

If a coefficient of absorption of plasma proteins of 0.87 is assumed, the additional losses of plasma protein (8.06 and $6.94 \mathrm{~g} / \mathrm{d}$ during weeks 7 and 17 , respectively) could be calculated to account for an extra 0.17 and $0.14 \mathrm{~g} \mathrm{~N} / \mathrm{d}$ at the ileum of infected animals at these times. The difference in NAN flow past the terminal ileum as a result of infection ranged from approximately $0.47-1.46 \mathrm{~g} \mathrm{NAN} / \mathrm{d}$. Plasma protein loss was therefore a relatively small component $(10-36 \%)$ of the increased ileal NAN flow, particularly during week 17, and other sources of endogenous protein loss must be implicated, presumably sloughed gastrointestinal tract epithelial cells and mucous proteins.

The flows of $\mathrm{N}$ and NAN along the small intestine (Tables 4 and 5) indicate a difference in the effect of parasitism between the two periods. During week 7 there was a net gain of NAN and total $\mathrm{N}$ between the abomasum and proximal jejunum which implies that endogenous protein losses occurred mainly at the site of infection with $T$. colubriformis. 
Ileal total $\mathrm{N}$ or NAN flow was not changed markedly by parasitism, in agreement with the previous conclusion that endogenous protein, particularly plasma protein, is largely reabsorbed in the distal small intestine. On the other hand, during week 17, a much greater net addition of total $\mathrm{N}$ and NAN occurred in the abomasum, presumably as a result of increased endogenous protein loss caused by infection with $O$. circumcincta. It may be that this reflected a greater pathogenicity of the second batch of larvae used after week 12 , or other factors which permitted better development of $O$. circumcincta in later stages of the trial. Increased losses into the abomasum appeared to have caused the elevated $N$ and NAN flow at the proximal jejunum during this period, and this was associated with the observation that plasma pepsinogen concentration increased between weeks 7 and 17. The plasma pepsinogen values, though low, compared to similar previous investigations (Sykes \& Coop, 1976; Symons et al. 1981; Coop et al. 1982, 1985). This rise normally occurs after about $8 \mathrm{~d}$ in simple infections with $O$. circumcincta (Coop et al. 1977), and there is more recent evidence that in concurrent infections with $T$. colubriformis and $O$. circumcincta the former may inhibit development of the latter (Sykes et al. 1988).

The $\mathrm{N}$ transactions along the gastrointestinal tract in the infected animals are largely in agreement with the trends observed in monospecific infections of Haemonchus contortus (Rowe et al. 1988) and T. colubriformis (Poppi et al. 1986). Taken together these studies indicate that the effect of gastrointestinal parasitism on the host is to increase endogenous protein loss rather than to cause malabsorption, and that plasma protein appears to be a minor component of the extra $\mathrm{N}$ leaving the ileum but its contribution to the total endogenous loss into the small intestine will depend on the absorption of other endogenous proteins. The extent to which sloughed epithelial cells and mucus can be digested and reabsorbed is not known, but if they are similar to bacterial protein $(0 \cdot 7$; Poppi et al. 1986) or plasma proteins $(0.87$; see p. 243) then the extra endogenous protein loss into the gastrointestinal tract of infected animals must be quite high (14-71 g protein $/ \mathrm{d})$. At least, assuming a digestion and absorption coefficient of zero for these sources, the extra loss would be $10-15 \mathrm{~g}$ protein/d. These values have obvious implications for the energy costs of replacement protein synthesis and possibly the requirement of specific amino acids in infected animals.

In other respects, the pathogenesis of infection was typical of these rates and patterns of infection (Dargie, 1980, Sykes, 1982), although the degree of hypoalbuminaemia and hyperglobulinaemia was low (Coop et al. 1977; Steel et al. 1980, 1982; Symons et al. 1981). The development of anorexia after 3 weeks coincided with the appearance of parasite eggs in the faeces after $21 \mathrm{~d}$ when adult parasites would have emerged from the mucosa (Soulsby, 1968). The extent of the anorexia tended to be severe by comparison with that observed in single-species infections (Sykes, 1982) and may reflect multiplicative effects of concurrent parasite infections for which there is recent evidence (Sykes et al. 1988).

The late establishment of pair-feeding during the third week post-infection, probably explains the $1.5 \mathrm{~kg}$ greater weight gain of infected animals during the first 3 weeks. The consistent $12 \%$ greater weight loss in infected than in pair-fed animals thereafter (Fig. 2) occurred despite similar values for $\mathrm{OM}$ and $\mathrm{N}$ digestibility. This agrees with findings of previous investigations (Coop et al. 1976, 1977, 1981; Sykes \& Coop, 1976, 1977). It was concluded that increased endogenous protein loss rather than impaired absorption was responsible for the adverse effect of parasitism.

The authors wish to thank Dr A. S. Familton for surgery, N. P. Jay, M. W. Lamming, P. Lord, J. Lassen, J. Haldane and S. Opie for technical assistance, R. W. McAnulty for parasitology, P. Wilson, G. Elmsly, R. Maxwell and J. Thackwell for chemical analysis, and B. W. Dow for assistance with statistical analysis. M. D. B. was in receipt of a Lincoln 
College Post-graduate Fellowship during the study which was funded with assistance from New Zealand Ministry of Agriculture \& Fisheries.

\section{REFERENCES}

Armstrong, D. G. \& Hutton, K. (1975). The fate of nitrogenous compounds entering the small intestine. In Digestion and Metabolism in the Ruminant, pp. 432-447 [I. W. McDonald and A. C. I. Warner, editors]. Armidale: University of New England Publishing Unit.

Barker, I. K. (1974). The relationship of abnormal mucosal microtopography with distribution of Trichostrongylus colubriformia in lambs. International Journal of Parasitology 4, 153-163.

Ben-Ghedalia, D., Tagari, H., Bondi, A. \& Tadmor, A. (1974). Protein digestion in the intestine of sheep. British Journal of Nutrition 31, 125-142.

Bown, M. D., Poppi, D. P. \& Sykes, A. R. (1984). The effect of a mixed nematode infection on the site of plasma protein absorption in the small intestine. Canadian Journal of Animal Science 64, Suppl., 197-198.

Bradstreet, R. B. (1965). The Kjeldahl Method for Organic Nitrogen. New York: Academic Press.

Coop, R. L., Angus, K. W. \& Sykes, A. R. (1979). The pathogenicity of chronic infection with Trichostrongy/us vitrinus in sheep. I. Pathological changes in the small intestine. Research in Veterinary Science 26, 363-371.

Coop, R. L., Graham, R. B., Jackson, F., Wright, S. E. \& Angus, K. W. (1985). Effect of experimental Ostertagia circumcincta infection in the performance of grazing ewes. Research in Veterinary Science 38, 282-287.

Coop, R. L., Sykes, A. R. \& Angus, K. W. (1976). Subclinical trichostrongylosis in growing lambs produced by continuous larval dosing. The effect on performance and certain plasma constituents. Research in Veterinary Science 21, 253-258.

Coop, R. L., Sykes, A. R. \& Angus, K. W. (1977). The effect of a daily intake of Ostertagia circumcincta larvae on body weight, food intake and concentration of serum constituents in sheep. Research in Veterinary Science 23, 76-83.

Coop, R. L., Sykes, A. R. \& Angus, K. W. (1982). The effect of three levels of intake of Ostertagia circumcincta larvae on growth rate, food intake and body composition in lambs. Journal of Agricultural Science, Cambridge 98, 247-255.

Coop, R. L., Sykes, A. R., Spence, J. A. \& Angus, K. W. (1981). Ostertagia circumcincta infection in lambs, the effect of different intakes of larvae on skeletal development. Journal of Comparative Pathology 91 521-530.

Dargie, J. D. (1980). The pathophysiology effects of gastro-intestinal and liver parasites in sheep. In Digestive Physiology and Metabolism in Ruminants, pp. 349-374 [Y. Ruckebusch and P. Thivend, editors]. Connecticut: AVI.

Downes, A. M. \& McDonald, I. W. (1964). The chromium-51 complex of ethylene-diamine tetra-acetic acid as a soluble rumen marker. British Journal of Nutrition 18, I53-162.

Faichney, G. J. (1975). The use of markers to partition digestion within the gastro-intestinal tract of ruminants. In Digestion and Metabolism in the Ruminant, pp. 277-291 [I. W. McDonald and A. C. I. Warner, editors]. Armidale: University of New England Publishing Unit.

Hecker, J. F. (1974). Experimental Surgery on Small Ruminants. London: Butterworths.

Herd, R. P. (1971). The pathogenic importance of Chabertia ovina (Fabricius, 1788) in experimentally infected sheep. International Journal for Parasitology 1, 25]-263.

Holmes, P. H. \& MacLean, J. M. (1971). The pathophysiology of ovine ostertagiasis: a study of the changes in plasma protein metabolism following single infections. Research in Veterinary Science 12, 265-271.

Jones, D. G. (1982). Changes in the intestinal enzyme activity of lambs during chronic infection with Trichostrongylus vitrinus. Research in Veterinary Science 32, 316-323.

Jones, W. O. (1979). A semi-automated method for plasma pepsinogen determination. Analytical Biochemistry 99 , $321-323$.

Lindsay, J. R., Hogan, J. P. \& Donnelly, J. P. (1980). The digestion of protein from forage diets in the small intestine of the sheep. Australian Journal of Agricultural Research 31, 589-600.

Ministry of Agriculture, Fisheries and Food (1979). Manual of veterinary parasitological laboratory techniques. Ministry of Agriculture Fisheries and Food, Agricultural Development and Advisory Service Technical Bulletin No. 18. London: H.M. Stationery office.

Poppi, D. P., MacRae, J. C., Brewer, A. \& Coop, R. L. (1986). Nitrogen transactions in the digestive tract of lambs exposed to the intestinal parasite Trichosirongylus colubriformis. British Journal of Nutrition 55, 593-602.

Richardson, R. I. \& Jouan, A. R. P. (1986). The distribution of peptidase activity in the small intestine of sheep. British Journal of Nutrition 55, 149-156.

Rowe, J. B., Nolan, J. V., De Chaneet, G., Teleni, E. \& Holmes, P. H. (1988). The effect of haemonchosis and blood loss into the abomasum on digestion in sheep. British Journal of Nutrition 59, 125-139.

Soulsby, E. J. L. (1968). Helminths, Arthropods and Protozoa of Domesticated Animals. Philadelphia, USA: Lea \& Febiger.

Steel, J. W., Jones, W. O. \& Symons, L. E. A. (1982). Effects of a concurrent infection of Trichostrongy/us colubriformis. Australian Journal of Agricultural Research 33, 131-140.

Steel, J. W., Symons, L. E. A. \& Jones, W. O. (1980). Effects of larval intake on the productivity and physiological 
and metabolic responses of lambs infected with Trichostrongylus colubriformis. Australian Journal of Agricultural Research 31, 821-838.

Sykes, A. R. (1982). Effects of parasitism on metabolism in the sheep. In Sheep Production, 35th Nottingham University Easter School, pp. 317-334 [W. Haresign, editor]. London: Butterworths.

Sykes, A. R. \& Coop, R. L. (1976). Intake and the utilisation of food by growing lambs with parasite damage to the small intestine by daily dosing with Trichostrongylus colubriformis larvae. Journal of Agricultural Science, Cambridge 86, 507-515.

Sykes, A. R. \& Coop, R. L. (1977). Intake and utilisation of food by growing sheep with abomasal damage caused by daily dosing with Ostertagia circumcincta larvae. Journal of Agricultural Science, Cambridge 88, 671-677.

Sykes, A. R., Poppi, D. P. \& Elliot, D. C. (1988). Effect of concurrent infection with Ostertagia circumcincta and Trichostrongylus colubriformis on the performance of growing lambs consuming fresh herbage. Journal of Agricultural Science 110, 531-541.

Symons, L. E. A. \& Jones, W. O. (1970). Nematospiroides dubius, Nippostrongylus brasiliensis and Trichostrongylus colubriformis: protein digestion in infected animals. Experimental Parasitology 27, 496-506.

Symons, L. E. A., Steel, J. W. \& Jones, W. O. (1981). Effects of larval intake on the productivity and physiological and metabolic responses of lambs infected with Ostertagia circumcincta. Australian Journal of Agricultural Research 32, 139-148.

Tan, T. N., Weston, R. H. \& Hogan, J. P. (1971). The use of ${ }^{103}$ Ru-labelled tris (1, 10-phenanthroline) Ruthenium II chloride as a marker in digestion studies with sheep. International Journal of Applied Radiation and Isotopes 22, 301-308.

Wolfson, W. Q., Cohn, C., Calvary, E. \& Ichiba, F. (1948). Studies in serum proteins. American Journal of Clinical Pathology 18, 723-730. 